\title{
PENERAPAN METODE CLUSTERING K-MEANS UNTUK PENGELOMPOKAN PRESTASI MAHASISWA DI POLITEKNIK LP3I BANDUNG
}

\author{
Tubagus Riko Rivanthio, S.Kom.
}

Program Studi Manajemen Informatika

Politeknik LP3I Bandung

J1.Pahlawan No. 59 Bandung, Indonesia

Email : riko_rivanthio@yahoo.com

\begin{abstract}
Abstrak : Penelitian ini bertujuan untuk mengelompokkan mahasiswa berdasarkan prestasi menggunakan teknik data mining dengan metode clustering K-Means. Hasil pengelompokkan mahasiswa diharapkan menjadi indikator bagi lembaga Politeknik LP3I Bandung dan pembimbing akademik mahasiswa dalam melakukan bimbingan terhadap mahasiswa.
\end{abstract}

Metode penelitian yang digunakan adalah menggunakan metode standar data mining yaitu Cross Industry Standard Process for Data Mining (CRISP-DM), dengan pemodelan yang digunakan adalah metode clustering, dimana pengklusteran merupakan pengelompokan record pengamatan, atau memperhatikan dan membentuk kelas objek-objek yang memiliki kemiripan. Sedangkan K-Means merupakan algoritma yang berisi tahapan dari pengelompokkan.

Berdasarkan hasil penelitian bahwa pengelompokkan menggunakan Clustering $K$ Means cukup efektif, Dari 368 data/mahasiswa terbentuk empat kelompok yang terdiri dari kluster pertama 13 data, kluster kedua 27 data, kluster ketiga 142, dan kluter keempat 186 data.

Kata Kunci : Penerapan Clutering K-Means, Prestasi Mahasiswa

\section{Pendahuluan}

\subsection{Latar Belakang}

Teknologi adalah penerapan dan pemanfaatan berbagai cabang Ilmu Pengetahuan yang menghasilkan nilai bagi pemenuhan kebutuhan dan kelangsungan hidup, serta peningkatan mutu kehidupan manusia (UU RI 2012 tentang Pendidikan Tinggi), Sedangkan definisi Informasi menurut Gordon B. Davis (1991: 28), bahwa Informasi adalah data yang telah diolah menjadi sebuah bentuk yang berarti bagi penerimanya dan bermanfaat bagi pengambilan keputusan saat ini atau mendatang. Maka dari pemaparan tersebut bahwa Teknologi Informasi dapat disimpulkan bahwa penerapan ilmu pengetahuan untuk mengolah data dalam pemenuhan kebutuhan manusia. Pada saat ini peranan teknologi informasi pada kebutuhan manusia sangatlah besar, contohnya pada dunia usaha bidang jasa, dengan adanya 
teknologi informasi pemberian informasi dan pelayanan kepada konsumen dapat dilakukan secara efektif dan efisien sehingga dapat meningkatkan kepuasan pelanggan.

Data Mining merupakan salah satu teknologi informasi yang banyak digunakan untuk menganalisa dan mengolah data menjadi informasi yang bermnafaat bagi penggunanya, sesuai dengan definisi dari Larose (2006) bahwa Data mining merupakan analisis dari peninjauan kumpulan data untuk menentukan hubungan yang tidak diduga dan meringkas data dengan cara berbeda sebelumnya, yang dapat dipahami dan bermanfaat bagi pemilik data. Pada saat ini data mining sering digunakan sebagai alat pendukung dalam pengambilan keputusan, seperti yang dipaparkan oleh Larose (2006) tentang contoh suatu kasus penentuan nasabah yang aman atau nasabah yang beresiko dalam pengajuan kredit pada suatu bank dengan menggunakan metode clustering yang merupakan salah satu dari enam metode yang terdapat pada data mining. Sedangkan pada dunia pendidikan terutama perguruan tinggi, data mining dapat digunakan untuk membantu perguruan tinggi dalam meningkatkan kualitas lulusan yang dihasilkan. Seperti halnya contoh kasus penentuan nasabah yang aman dan nasabah yang beresiko, metode pada contoh kasus tersebut dapat diterapkan dalam menganalisa dan memprediksi mahasiswa yang akan berprestasi dan yang kurang berprestasi. Clustering merupakan salah satu metode penggalian data pada data mining. Menurut Larose (2006) bahwa Clustering adalah pengelompokan record pengamatan, atau memperhatikan dan membentuk kelas objek-objek yang memiliki kemiripan.

Politeknik LP3I Bandung merupakan salah satu perguruan tinggi yang mempunyai visi menghasilkan sumber daya professional, beriman dan bertaqwa, maka dari Politeknik LP3I Bandung selalu mengutamakan kualitas dari setiap lulusannya. Karena lulusan Politeknik LP3I Bandung akan langsung disalurkan ke perusahaan yang telah bekerja masa dengan Politeknik LP3I Bandung. Salah satu upaya untuk menghasilkan lulusan yang berkualitas adalah melakukan pengawasan pada prestasi akademik mahasiswa oleh dosen pembimbing akademik. Sesuai dengan arahan Direktur yang tertuang dalam Standar Operasional Prosesur (SOP) Politeknik LP3I Bandung, Dosen Pembimbing Akademik wajib memberikan pengawasan terhadap prestasi akademik mahasiswa dan wajib memberikan peringatan kepada mahasiswa jika nilai prestasi akademik mahasiswa tidak sesuai standar di Politeknik LP3I Bandung yaitu memiliki Indek Prestasi Kumulatif 3,25 .

Namun dalam melakukan pengawasannya, dosen pembimbing akademik tidak mempunyai suatu indikator yang dapat digunakan untuk memprediksi prestasi akademik mahasiswa. Prediksi prestasi mahasiswa dapat digunakan untuk memberikan gambaran kepada mahasiswa tentang hasil akhir prestasi akademik yang akan diperolehnya. Prediksi prestasi akademik juga dapat digunakan sebagai peringatan awal kepada mahasiwa agar mahasiswa 
menjadi lulusan yang berkualitas yang mempunyai nilai prestasi akademik sesuai dengan standar Politeknik LP3I Bandung.

Pada penelitian ini, peneliti mencoba untuk menerapkan data mining dengan menggunakan metode clustering pada pengelompokan mahasiswa berdasarkan pretasi akademik yang diperoleh, pengelompokkan ini diharapkan menjadi suatu indikator bagi Dosen Pembimbing dan lembaga Politeknik LP3I Bandung untuk memberikan bimbingan kepada mahasiswa.

\subsection{Rumusan Masalah}

Permasalahan yang akan dibahas pada penelitian ini adalah bagaimana melakukan pengelompokan (Clustering) mahasiswa berdasarkan Indeks Prestasi Kumulatif, rata-rata jumlah kehadiran dan atribut tes psikotes seperti kemampuan intelektual, kemampuan khusus, kepribadian

\section{Tinjauan Pustaka}

\subsection{Data Mining}

Beberapa pengertian yang data mining yang diperoleh dari berbagai sumber antara lain :

1. Tan (2006) mendefinisikan data mining sebagai proses untuk mendapatkan informasi yang berguna dari gudang basis data yang besar.

2. Daniel Larose dalam buku Discovering Knowledge in Data : An Introduction to data Mining mengatakan bahwa :

"Data mining merupakan analisis dari peninjauan kumpulan data untuk menentukan hubungan yang tidak diduga dan meringkas data dengan cara berbeda sebelumnya, yang dapat dipahami dan bermanfaat bagi pemilik data"

3. Han (2001) dalam bukunya yang berjudul "Data Mining Concepts and Techniques Second Edition" mengungkapkan bahwa :

"Data mining merupakan proses pengekstrakan informasi dari jumlah kumpulan data yang besar dengan menggunakan algoritma dan tehnik gambar dari statistik, mesin pembelajaran dan sistem manajemen database".

\subsection{Kelompok Data Mining berdasarkan tugasnya}

Data mining dibagi menjadi beberapa kelompok berdasarkan tugas yang dapat dilakukan, yaitu (Larose, 2006)

1. Deskripsi

Terkadang peneliti dan analis secara sederhana ingin mencoba mencari cara untuk menggambarkan pola dan kecenderungan yang terdapat dalam data. Deskripsi dari pola dan kecenderungan sering memberikan kemungkinan penjelasan untuk suatu pola atau kecenderungan.

2. Estimasi

Estimasi hampir sama dengan klasifikasi, kecuali variable target estimasi lebih kea rah numeric daripada ke arah kategori. Model dibangun 
menggunakan record lengkap yang menyediakan nilai dari variable target sebagai nilai prediksi. Selanjutnya, pada peninjauan berikutnya estimasi nilai dari variable target dibuat berdasarkan nilai variable prediksi.

3. Prediksi

Prediksi hampir sama dengan dengan klasifikasi dan estimasi, kecuali bahwa dalam prediksi nilai dari hasil aka nada dimasa mendatang.

4. Klasifikasi

Dalam klasifikasi,terdapat target variable kategori. Sebagai contoh, penggolongan pendapatan dapat dipisahkan dalam tiga kategori yaitu pendapatan tinggi, pendapatan sedang, dan pendapatan rendah.

5. Pengklusteran

Pengklusteran merupakan pengelompokan record pengamatan, atau memperhatikan dan membentuk kelas objek-objek yang memiliki kemiripan.

6. Asosiasi

Tugas asosiasi dalam data mining adalah menentukan atribut yang muncul dalam satu waktu.

\subsection{Cross Industry Standard Process for Data Mining (CRISP-DM)}

Menurut Daniel T. Larose (2006), Cross-Industry Standart Process for Data Mining (CRISP-DM) yang dikembangkan tahun 1996 oleh analisis dari beberapa industri seperti Daimler Chrysler, SPSS dan NCR. CRISP-DM menyediakan standar proses data mining sebagai strategi pemecahan masalah secara umum dari bisnis atau unit penelitian.

Dalam CRISP-DM sebuah proyek data mining memiliki siklus hidup yang terbagi dalam enam fase Gambar 1 Keseluruhan fase berurutan yang ada tersebut bersifat adaptif. Fase berikutnya dalam urutan bergantung kepada keluaran dari fase sebelumnya. Hubungan penting antar fase digambarkan dengan panah. Sebagai contoh, jika proses berada pada fase modeling. Berdasar pada perilaku dan karakteristik model, proses mungkin kembali kepada fase data preparation untuk perbaikan lebih lanjut terhadap data atau berpindah maju kepada fase evaluation

Enam fase CRISP-DM (Cross Industry Standard Process for Data Mining) (Larose, 2006).

1. Business Understanding Phase (Fase Pemahaman Bisnis)

a. Penentuan tujuan proyek dan kebutuhan secara detail dalam lingkup bisnis atau unit penelitian secara keseluruhan.

b. Menerjemahkan tujuan dan batasan menjadi formula dari permasalahan data mining.

c. Menyiapkan strategi awal untuk mencapai tujuan.

2. Data Understanding Phase (Fase Pemahaman Data)

a. Mengumpulkan data.

b. Menggunakan analisis penyelidikan data untuk mengenali lebih lanjut data dan pencarian pengetahuan awal.

c. Mengevaluasi kualitas data. 
d. Jika diinginkan, pilih sebagian kecil kelompok data yang mungkin mengandung pola dari permasalahan

3. Data Preparation Phase (Fase Pengolahan Data)

a. Siapkan dari data awal, kumpulan data yang akan digunakan untuk keseluruhan fase berikutnya. Fase ini merupakan pekerjaan berat yang perlu dilaksanakan secara intensif.

b. Pilih kasus dan variabel yang ingin dianalisis dan yang sesuai analisis yang akan dilakukan.

c. Lakukan perubahan pada beberapa variabel jika dibutuhkan.

d. Siapkan data awal sehingga siap untuk perangkat pemodelan.

4. Modeling Phase (Fase Pemodelan)

a. Pilih dan aplikasikan teknik pemodelan yang sesuai.

b. Kalibrasi aturan model untuk mengoptimalkan hasil.

c. Perlu diperhatikan bahwa beberapa teknik mungkin untuk digunakan pada permasalahan data mining yang sama.

d. Jika diperlukan, proses dapat kembali ke fase pengolahan data untuk menjadikan data ke dalam bentuk yang sesuai dengan spesifikasi kebutuhan teknik data mining tertentu.

5. Evaluation Phase (Fase Evaluasi)

a. Mengevaluasi satu atau lebih model yang digunakan dalam fase pemodelan untuk mendapatkan kualitas dan efektivitas sebelum disebarkan untuk digunakan.

b. Menetapkan apakah terdapat model yang memenuhi tujuan pada fase awal.

c. Menentukan apakah terdapat permasalahan penting dari bisnis atau penelitian yang tidak tertangani dengan baik.

d. Mengambil keputusan berkaitan dengan penggunaan hasil dari data mining.

6. Deployment Phase (Fase Penyebaran)

a. Menggunakan model yang dihasilkan. Terbentuknya model tidak menandakan telah terselesaikannya proyek.

b. Contoh sederhana penyebaran: Pembuatan laporan.

c. Contoh kompleks Penyebaran: Penerapan proses data mining secara paralel pada departemen lain.

\subsection{Metode Clustering}

Menurut Larose (2006) Clustering mengacu pada pengelompokan catatan, observasi, atau kasus ke dalam kelas benda serupa. Sebuah cluster adalah kumpulan dari catatan yang mirip satu sama lain dan berbeda dengan catatan dalam cluster lain. Clustering berbeda dengan classification yang tidak ada variabel target untuk clustering. Pengelompokan tugas tidak mencoba untuk mengklasifikasikan,memperkirakan, atau memprediksi nilai variabel sasaran. Sebaliknya, algoritma klasterisasi mencari ke segmen data seluruh set menjadi subkelompok yang relatif homogen atau kelompok, di mana kesamaan catatan dalam cluster dimaksimalkan, dan kesamaan catatan luar klaster ini diminimalkan. 


\subsection{Algoritma K-Means}

Menurut Larose (2006) Algoritma k-means clustering algoritma sederhana dan efektif untuk menemukan cluster dalam data. Proses algoritmanya adalah sebagai berikut:

1. Langkah pertama : Tentukan berapa banyak klaster $\mathrm{k}$ dari dataset yang akan dibagi.

2. Langkah kedua : Tetapkan secara acak data k menjadi pusat awal lokasi klaster.

3. Langkah ketiga : Untuk masing-masing data, temukan pusat klaster terdekat. Dengan demikian berarti masingmasing pusat klaster memiliki sebuah subset dari dataset, sehingga mewakili bagian dari dataset. Oleh karena itu, telah terbentuk klaster $\mathrm{k}: \mathrm{C} 1, \mathrm{C} 2, \mathrm{C} 3, \ldots, \mathrm{Ck}$.

4. Langkah keempat : Untuk masing-masing klaster $\mathrm{k}$, temukan pusat luasan klaster, dan perbarui lokasi dari masing-masing pusat klaster ke nilai baru dari pusat luasan.

5. Langkah kelima Ulangi langkah ke-3 dan ke-5 hingga data-data pada tiap klaster menjadi terpusat atau selesai.

\section{Obyek dan Metoda Penelitian}

\subsection{Obyek Penelitian}

Penelitian dilakukan di Politeknik LP3I Bandung, dengan menggunakan data mahasiswa angkatan 2010 dari semua program studi yang ada di Politeknik LP3I Bandung yaitu Program Studi Administrasi Bisnis, Manajemen Informatika, Akuntansi, Hubungan Masyarakat.

Politeknik LP3I Bandung merupakan salah satu lembaga pendidikan tinggi yang bernaung dibawah bendera LP3I Grup. Kiprahnya dihadirkan sebagai lanjutan program profesi yang telah hadir di dunia pendidikan Indonesia selama kurang lebih 20 tahun. Dengan format "Vocational based Polytechnic", maka Politeknik LP3I Bandung memproyeksikan seluruh mahasiswanya dipromosikan untuk magang dan kerja sebelum lulus kuliah sesuai dengan ketentuan yang berlaku. Politeknik LP3I Bandung memiliki empat program studi yaitu Administrasi Bisnis, Manajemen Informatika, Akuntasi dan Hubungan Masyarakat (Sumber : Buku Selayang Pandang Politeknik LP3I Bandung).

\subsection{Metoda Penelitian}

Cross Industry Standard Process for Data Mining (CRISP-DM) digunakan sebagai standard proses data mining sekaligus sebagai metode penelitian. Dalam CRISP-DM terdapat enam fase atau tahapan proses yang terdiri dari :

1. Business Understanding Phase (Fase Pemahaman Bisnis)

Tujuan dari penelitian ini adalah menganalisa kesesuaian pemilihan program studi oleh mahasiswa dengan menggunakan teknik data mining yaitu metode clustering (pengelompokkan) berdasarkan atribut-atribut yang dimiliki oleh mahasiswa yaitu

2. Data Preparation Phase (Fase Pengolahan Data) 
Langkah selanjutnya adalah fase pengolahan data, dalam fase ini ada berapa tahapan dalam pengolahan data yaitu

a. Pengumpulan data, yang diambil dari Sistem Informasi Akademik (SIAKAD Politeknik LP3I Bandung)

b. Menyeleksi atau pembersihan data untuk penentuan atribut yang akan digunakan, adapun atribut yang digunakan adalah :

Tabel Variabel yang digunakan

\begin{tabular}{|c|l|l|}
\hline No & \multicolumn{1}{|c|}{ Atribut } & \multicolumn{1}{c|}{ Deskripsi } \\
\hline 1 & $\begin{array}{l}\text { Rata-rata } \\
\text { kehadiran } \\
\text { mahasiswa }\end{array}$ & $\begin{array}{l}\text { Rata-rata kehadiran mahasiswa adalah nilai yang } \\
\text { dijadikan sebagai perwakilan dari kumpulan jumlah } \\
\text { kehadiran setiap mata kuliah. }\end{array}$ \\
\hline 2 & $\begin{array}{l}\text { Indeks Prestasi } \\
\text { Kumulatif (IPK) }\end{array}$ & $\begin{array}{l}\text { Indeks Prestasi Kumulatif (IPK) adalah penilaian } \\
\text { keseluruhan prestasi terhadap mahasiswa dalam } \\
\text { sistem perkuliahan selama masa kuliah yaitu } \\
\text { penilaian dari semester satu sampai semester enam }\end{array}$ \\
\hline 3 & $\begin{array}{l}\text { Hasil Tes } \\
\text { psikotest } \\
\text { mahasiswa }\end{array}$ & $\begin{array}{l}\text { Hasil Tes Psikotest Mahasiswa adalah hasil dari } \\
\text { pengujian untuk mengukur aspek-aspek individu } \\
\text { mahasiswa, aspek yang diukur adalah } \\
\text { Kemampuan Intelektual, Kepribadian, Sikap Kerja, } \\
\text { dan Kemampuan Khusus }\end{array}$ \\
\hline
\end{tabular}

c. Melakukan transformasi data yaitu merubah data disesuaikan dengan kebutuhan tool/software yang akan digunakan pada tahap fase pemodelan, seperti data bentuk teks menjadi angka, adapun hasil dari tranformasi data hanyalah atribut hasil tes psikotes saja, yaitu sebagai berikut :

Tabel Transformasi Hasil Tes Psikotest

\begin{tabular}{|l|c|}
\hline \multicolumn{1}{|c|}{ Hasil Psikotest } & Nilai Angka \\
\hline Sangat Baik & 4 \\
\hline Baik & 3 \\
\hline Cukup & 2 \\
\hline Kurang & 1 \\
\hline
\end{tabular}

3. Modeling Phase (Fase Pemodelan)

Sesuai dengan tujuan dari penelitian ini adalah pengelompokkan mahasiswa berdasarkan prestasi mahasiswa dengan menggunakan metoda clustering, dan algoritma yang digunakan adalah algoritma K-Means

4. Evaluation Phase (Fase Evaluasi)

Melakukan pengecekan terhadap setiap nilai atribut dan model yang sudah dibangun. Kemudian melakukan evaluasi terhadap hasil dengan melakukan analisis dari setiap variabel target atau karakteristik informasi yang dihasilkan oleh model penggalian data. Pada tahap ini juga merupakan tahapan dimana dilakukan perbaikan kembali bila terjadi kekurangan. Pada tahapan ini bisa saja kembali lagi ke fase yang pertama dan kemudian ke fase berikutnya 
dengan tujuan perbaikan, sampai sesuai dengan kebutuhan. Seterusnya adalah tahapan Pelaksanaan yang merupakan tahapan akhir dalam pengembangan data mining

5. Deployment Phase (Fase Penyebaran)

Pada penelitian ini pengetahuan penggalian data (data mining) akan digunakan langsung oleh business users, yaitu antara lain lembaga Politeknik LP3I Bandung dan Dosen Pembimbing Akademik, hasil pengetahuan penggalian diharapkan menjadi alat bantu institusi dan dosen pembimbing akademik untuk memberikan peringatan dini kepada mahasiswa semester dua, terhadap hasil yang akan diraih jika melihat dari atribut atau data-data yang dimiliki pada saat semester dua

\section{Hasil Penelitian dan Pembahasan}

\subsection{Detail Penelitian dan Hasil Penelitian}

1. Langkah pertama : Banyaknya kelompok adalah 4, dimana terdiri dari kelompok pretasi cumlaude, kelompok pretasi sangat memuaskan, kelompok prestasi memuaskan dan kelompok prestasi Cukup

2. Langkah kedua : menentukan secara acak data $\mathrm{k}$ menjadi pusat awal lokasi klaster/kelompok.

3. Langkah ketiga : Untuk masing-masing data, temukan pusat klaster terdekat. Dengan demikian berarti masingmasing pusat klaster memiliki sebuah subset dari dataset, sehingga mewakili bagian dari dataset. Oleh karena itu, telah terbentuk klaster $\mathrm{k}$ : C1, C2, C3, C4, dan hasilnya adalah

Initial Cluster Centers

\begin{tabular}{|c|r|r|r|r|}
\hline \multirow{2}{*}{} & \multicolumn{4}{|c|}{ Cluster } \\
\cline { 2 - 5 } & 1 & 2 & 3 & 4 \\
\hline $\begin{array}{c}\text { Kemampuan } \\
\text { Intelektual }\end{array}$ & 1 & 1 & 2 & 3 \\
Kepribadian & 2 & 1 & 2 & 3 \\
Sikap Kerja & 2 & 1 & 2 & 3 \\
Kemampuan \\
Khusus
\end{tabular}

4. Langkah keempat : Untuk masing-masing klaster $\mathrm{k}$, temukan pusat luasan klaster, dan perbarui lokasi dari masing-masing pusat klaster ke nilai baru dari pusat luasan. 
5. Langkah kelima Ulangi langkah ketiga hingga keempat hingga data-data pada tiap klaster menjadi terpusat atau selesai

\subsection{Pembahasan}

Berikut ini adalah pengelompokan yang terbentuk dari hasil clustering menggunakan algoritma K-Means.

\section{Final Cluster Centers}

\begin{tabular}{|l|r|r|r|r|}
\hline & \multicolumn{4}{|c|}{ Cluster } \\
\cline { 2 - 5 } & 1 & \multicolumn{1}{|c|}{2} & \multicolumn{1}{|c|}{3} & \multicolumn{1}{|c|}{4} \\
\hline Kemampuan & 2 & 1 & 2 & 3 \\
Intelektual & 2 & 2 & 2 & 3 \\
Kepribadian & 1 & 1 & 2 & 3 \\
Sikap Kerja & 2 & 1 & 2 & 3 \\
Kemampuan Khusus & 1,22 & 2,24 & 3,09 & 3,52 \\
IPK & & & \\
\hline
\end{tabular}

\section{Jumlah Data Setiap Kluster}

\begin{tabular}{|l|l|r|}
\hline \multirow{4}{*}{ Cluster } & 1 & 13,000 \\
\cline { 2 - 3 } & 2 & 27,000 \\
\cline { 2 - 3 } & 3 & 142,000 \\
\cline { 2 - 3 } & 4 & 186,000 \\
\hline Valid & 368,000 \\
\hline Missing &, 000 \\
\hline
\end{tabular}

Berdasarkan dari tabel diatas, maka dapat disimpulkan bahwa pada

1. Kluster pertama yaitu kelompok yang memiliki IPK dengan rata-rata 1,2 dengan hasil tes potensi akademik dengan atribut kemampuan intelektual, kepribadian, kemampuan khusus memiliki nilai rata-rata 2, dan sikap kerja nilai rata-rata 1, sehingga kluster pertama ini dapat dikategorikan pada kelompok prestasi cukup.

2. Kluster kedua yaitu kelompok yang memiliki IPK dengan rata-rata 2,24 dengan hasil tes potensi akademik dengan atribut kemampuan intelektual, sikap kerja, kemampuan khusus memiliki nilai rata-rata 1, dan kepribadian nilai rata-rata 2 , sehingga kluster pertama ini dapat dikategorikan pada kelompok prestasi memuaskan.

3. Kluster ketiga yaitu kelompok yang memiliki IPK dengan rata-rata 2,24 dengan hasil tes potensi akademik dengan atribut kemampuan intelektual, sikap kerja, kemampuan khusus dan kepribadian memiliki nilai rata-rata 2, sehingga kluster pertama ini dapat dikategorikan pada kelompok prestasi memuaskan

4. Kluster ketiga yaitu kelompok yang memiliki IPK dengan rata-rata 3,5 dengan hasil tes potensi akademik dengan atribut kemampuan intelektual, sikap kerja, kemampuan khusus dan kepribadian memiliki nilai rata-rata 
3, sehingga kluster pertama ini dapat dikategorikan pada kelompok prestasi memuaskan

\section{Kesimpulan dan Saran}

\subsection{Kesimpulan}

Berdasarkan hasil penelitian dari penerapan data mining pada pengelompokan prestasi mahasiswa dengan menggunakan clustering K-Means di Politeknik LP3I Bandung, maka dapat diambil kesimpulan bahwa :

1. Clustering K-Means dapat menghasilkan kelompok-kelompok prestasi mahasiswa sesuai dengan jumlah kelompok yang diinginkan, pengelompokkan didasari dengan menggunakan atribut IPK dan atribut hasil tes potensi akademik yang terdiri dari kemampuan intelektual, kepribadian, sikap kerja dan kemampuan khusus.

2. Kelompok yang dihasilkan Clusterinng K-Means dapat dijadikan sebagai indikator oleh lembaga Politeknik LP3I Bandung dan dosen pembimbing akademik dalam melakukan pembimbingan terhadap mahasiswa, terutama terhadap mahasiswa baru yang memiliki tes potensi akademik dengan nilai rata-rata 1 dan 2.

\subsection{Saran}

Adapun saran-saran terhadap penelitian ini adalah :

1. Pengembangan metoda data mining dengan menggunakan algoritma yang termasuk pada clustering dan penambahan atribut/variable dari data profil yang dimilik oleh mahasiswa.

2. Penerapan clustering K-Means dapat digunakan untuk pengelompokkan mahasiswa untuk membentuk kelas-kelas belajar sehingga pembelajaran lebih efektif, sehingga menghasilkan lulusan yang berkualitas.

\section{Daftar Pustaka}

[1] Han, Jiawei; \& Kamber, Micheline. Data Mining Concepts and Techniques Second Edition. San Francisco: Morgan Kauffman, 2001

[2] Larose, Daniel Discovering Knowledge in Data : An Introduction to data Mining, 2005

[3] Tan, P; Steinbach; \& Kumar, V. Introduction to Data Mining.Pearson Education 2006.

[4] Undang-Undang Republik Indonesia Tahun 2012 Tentang Pendidikan Tinggi 